\title{
Pengaruh Profitabilitas, Price Earning Ratio, Debt to Equity Ratio dan EarningPer Share terhadap Nilai Perusahaan sektor Pertanian Go Public
}

\author{
Rinaldi \\ rinaldinanan@gmail.com
}

\begin{abstract}
Abstrak
Penelitian ini bertujuan untuk menganalisis pengaruh profitabilitas, price earning ratio, debt to equity ratio dan earning per share terhadap nilai perusahaan sektor pertanian yang telah go public dengan pengamatan dari tahun 2008 - 2014. Data yang digunakan merupakan data sekunder dan metode analisis menggunakan soft ware eviews 8 untuk mendapatkan gambaran pengaruh variabel satu dengan variabel lainnya. Jumlah sampel dalam penelitian ini sebanyak 8 (delapan) perusahaan pertanian dan metode pengambilan sampel menggunakan purposive sampling. Pengujian hipotesis dilakukan dengan dua tahap yaitu 1)Menguji pengaruh profitabilitas, PER, DER dan EPS secara parsial terhadap nilai perusahaan. 2)Menguji pengaruh profitabilitas, PER, DER dan EPS secara simultan terhadap nilai perusahaan.

Hasil penelitian ini adalah 1)Profitabilitas berpengaruh positif tidak signifikan terhadap nilai perusahaan. 2)Price Earning Ratio berpengaruh positif tidak signifikan terhadap nilai perusahaan. 3)Debt to Equity Ratio berpengaruh negatif tidak signifikan terhadap nilai perusahaan. 4)Earning Per Share berpengaruh positif signifikan terhadap nilai perusahaan. 5) Profitabilitas, Price Earning Ratio, Debt to Equity Ratio dan Earning per Share secara bersamasama (simultan) berpengaruh terhadap nilai perusahaan.
\end{abstract}

Kata kunci: Nilai Perusahaan,Profitabilitas, Price Earning Ratio, Debt to Equity Ratio, Earning Per Share

\section{PENDAHULUAN}

Secara umum tujuan dari suatu perusahaan adalah untuk memperoleh laba atau keuntungan ekonomis secara maksimum. Selain untuk memperoleh keuntungan secara maksimum tujuan utama lainnya adalah untuk memakmurkan pemilik perusahaan atau pemilik saham dengan memaksimalkan nilai perusahaan (Brigham\& Houston, 2006).

Nilai perusahaan yang tinggi akan diikuti dengan tingginya kemakmuran 
pemilik dan pemegang saham perusahaan, hal ini tercermin pada harga sahamnya. Setiap perusahaan menginginkan harga saham yang dijual memiliki potensi harga tinggi sehingga menarik investor untuk membelinya. Semakin tinggi harga saham semakin tinggi nilai perusahaan,dengan nilai perusahaan yang tinggi akan diikuti dengan tingginya kemakmuran pemilik dan pemegang saham perusahaan, hal ini tercermin pada harga sahamnya. Setiap perusahaan menginginkan harga saham yang dijual memiliki potensi harga tinggi sehingga menarik investor untuk membelinya. Semakin tinggi harga saham semakin tinggi nilai perusahaan, Salah satu sektor di Bursa Efek Indonesia adalah sektor pertanian. Sektor pertanian bergerak dibidang perkebunan, peternakan , perikanan dan lainnya. Sektor pertanian merupakan sektor yang berperan penting dalam perekonomian nasional, kelangsungan hidup masyarakat, penyedia papan , pangan, lapangan kerja. Permasalahan yang dihadapi perusahaan-perusahaan sektor pertanian adalah menurunnya nilai perusahaan. Berikut adalah data nilai perusahaan sektor pertanian berdasarkan Tobins' $q$
Tabel 1.1.

Nilai Perusahaan sektor pertanian berdasarkan Tobins'q

\begin{tabular}{|c|c|c|c|c|c|}
\hline Perusahaan & 2010 & 2011 & 2012 & 2013 & 2014 \\
\hline Astra Agro Lestani Tbk & 4,84 & 0,18 & 2,74 & 2,96 & 2,42 \\
\hline BISI Intemational & 4,22 & 1,95 & 1,62 & 1,12 & 1,41 \\
\hline Dhama Samudera Intemational Tbk & 1,49 & 1,35 & 1,08 & 0,96 & 1,93 \\
\hline Gozco Plantantions Tbk & 1,34 & 0,94 & 0,87 & 0,74 & 0,77 \\
\hline London Sumatera Plantation Tbk & 0,43 & 2,40 & 2,25 & 1,82 & 1,66 \\
\hline Sampoema Agro Tbk & 2,34 & 1,92 & 1,50 & 1,24 & 7,76 \\
\hline SMARTTBk & 1,68 & 1,75 & 1,61 & 1,87 & 1,72 \\
\hline Tunas Banu Lampung Tbk & 1,19 & 1,31 & 1,13 & 1,08 & 1,21 \\
\hline Rata-rata Tobins'y & 2,19 & 1,48 & 1,60 & 1,47 & 2,36 \\
\hline$\overline{\Delta(\%)}$ & - & $-32,42$ & 8,11 & 8,13 & $\overline{60,54}$ \\
\hline \multicolumn{6}{|c|}{$\begin{array}{l}\text { Sumber:HasilOlahan, } 2015 \\
\text { Profitabilitas merupakan kemampuan } \\
\text { perusahaan untuk memperoleh laba melalui } \\
\text { semua kemampuan dan sumber daya yang } \\
\text { ada. Tingkat profitabilitas yang tinggi } \\
\text { menunjukan prospek perusahaan yang baik, } \\
\text { terutama dalam membagikan dividen kepada } \\
\text { pemegang saham, artinya nilai perusahaan } \\
\text { juga dinilai semakin baik dimata investor. } \\
\text { Dalam penelitian ini profitabilitas diukur } \\
\text { dengan ROA. Berikut disajikan Nilai ROA } \\
\text { beberapa perusahaan sektor pertanian. }\end{array}$} \\
\hline
\end{tabular}


Tabel 1.2

Nilai ROA perusahaan sektor pertanian

\begin{tabular}{|l|c|c|c|c|}
\hline \multicolumn{1}{|c|}{ Perusahaan } & $\mathbf{2 0 1 0}$ & $\mathbf{2 0 1 1}$ & $\mathbf{2 0 1 2}$ & $\mathbf{2 0 1}$ \\
\hline Astra Agro Lestan Tbk & 22,94 & 24,48 & 20,29 & 12,7 \\
\hline BISI Intemational & 10,49 & 9,74 & 8,12 & 7,4 \\
\hline Dhamma Samudera Intemational Tbk & 3,42 & 4,32 & 21,62 & 4,7 \\
\hline Gozco Plantantions Tbk & 7,68 & 5,93 & 3,09 & 2,9 \\
\hline London Sumatera Plantation Tbk & 18,58 & 30,77 & 18,17 & 9,64 \\
\hline Sampoema Agro Tbk & 21,20 & 16,12 & 8,12 & 2,6 \\
\hline SMART Tbk & 10,11 & 12,74 & 13,41 & 4,86 \\
\hline Tunas Baru Lampung Tbk & 6,77 & 10,39 & 4,69 & 1,3 \\
\hline Rata-rata & 12,65 & 14,31 & 12,19 & 5,80 \\
\hline$\Delta$ (\%) & - & 13,12 & $-14,81$ & $-52,4$ \\
\hline
\end{tabular}

Retunr Ö Ásset merupakan ukuran kemampuan perusahaan dalam menghasilkan keuntungan (return) bagi perusahaan dengan memanfaatkan aktiva yang dimiliki (Tandelilin 2010; 378). Semakin besar ROA menunjukan kinerja perusahaan semakin baik,dan menunjukan bahwa perusahaan semakin efisien dalam memanfaatkan aktivanya untuk memperoleh laba, sehingga nilai perusahaan meningkat. Nilai perusahaan dapat pula dipengaruhi oleh price earning ratio, yang menunjukan rasio dari harga saham terhadap earning.Price Earning Ratio menunjukan berapa banyak investor bersedia membayar untuk tiap rupiah dari laba yang dilaporkan atau seberapa besar investor menilai harga dari saham terhadap kelipatan dari earning (Hartono, 2010; 146).

Teori struktur modal menjelaskan bahwa kebijakan pendanaan perusahaan dalam menentukan struktur modal (bauran antara hutang dan ekuitas) bertujuan untuk mengoptimalkan nilai perusahaan. Trade off theory dan pecking order theory berpendapat bahwa dalam pasar modal yang sempurna dan tidak ada pajak, nilai perusahaan atau biaya modal perusahaan dapat dirubah dengan cara merubah struktur modal, Husnan ( 2005; 294). Struktur modal dapat diukur dengan Debt to Equity Ratio (DER) yaitu total hutang dibagi dengan total 13 eleviltas

\section{4,12 .}

Earning Per Share (EPS), merupakan rasio ${ }^{41}$ untuik mengukur kemampuan perusahaan 71 dalam menghasilkan keuntungan bersih dari setiap lembar saham biasa yang beredar. EPS yang tinggi menunjukan kemampuan perúsahaan yang lebih besar dalam 2,66 métighasilkan keuntungan bersih dari setiap s6 leñbar saham dan mengakibatkan peningkatan kemakmuran investor dan akan mendorong investor untuk menambah ${ }^{80}$ jumílah modal yang ditanamkan pada +2percesahaan. Investasi ini akan mengakibatkan kenaikan laba perusahaan dan juga mengakibatkan kenaikan harga saham dan akhirnya menaikan nilai perusahaan.

Hasil penelitian yang dilakukan Wulandari (2013) berkesimpulan bahwa ReturnOn Assets berpengaruh signifikan terhadap Nilai Perusahaan. Sedangkan Wibowo dan Aisjah (2012) hasil penelitiannya menyimpulkan bahwa Return On Assets tidak berpengaruh terhadap Nilai perusahaan.

Hasil penelitian Nasehah dan Widyarti (2012), Wibowo dan Aisjah (2012), Debt to Equity Ratio berpengaruh negatif terhadap Nilai Perusahaan. Sedangkan penelitian Fenandar dan Rahardja (2012), hasil penelitiannya Debt to EquityRatio tidak berpengaruh terhadap Nilai Perusahaan.

Sartini dan Purbawangsa (2012) dan Gayatri dan Mustanda (2012), hasil penelitiannya berkesimpulan price earning ratio berpengaruh signifikan terhadap Nilai Perusahaan. Sedangkan hasil penelitian yang dilakukakan Poernamawatie (2008), menunjukan bahwa price earning ratio tidak berpengaruh terhadap return saham sedangkan price to bookvalue berpengaruh 
lebih dominan mempengaruhi return saham dibandingkan price earning ratio.

Penelitian Asri (2012) dan Irayanti dan Tumbel (2014), menyimpulkan bahwa EPS berpengaruh signifikan terhadap nilai

Berdasarkan uraian hasil penelitian diatas, maka patut diduga bahwa terdapat inkonsistensi teori untuk dapat menjelaskan fenomena yang terjadi. Hal ini menyebabkan penulis tertarik untuk meneliti Return On Assets, Price Earning Ratio (PER), Debt to Equity Ratio (DER) dan Earning Per Share (EPS) dan pengaruhnya terhadap Nilai Perusahaan yang diukur dengan metode Tobins'q pada perusahaan sektor pertanian yang terdaftar di Bursa Efek Indonesia.

\section{LANDASAN TEORI}

\subsection{Nilai Perusahaan}

Nilai perusahaan tidak hanya bergantung pada kemampuan menghasilkan arus kas, tetapi juga bergantung pada karakteristik operasional dan keuangan dari perusahaan. Beberapa variabel kuantitatif yang sering digunakan untuk memperkirakan nilai perusahaan adalah sebagai berikut Keown et al ( 2004;849): a) Nilai Buku b) Nilai apprraisal c) Nilai Pasar Saham d) Nilai Chop - Shop dan e) Nilai Arus Kas.

Rasio-rasio keuangan digunakan investor untuk mengetahui nilai perusahaan. Rasio keuangan tersebut dapat memberikan indikasi bagi manajemen mengenai penilaian investor terhadap kinerja perusahaan dimasa lampau dan prospek dimasa yang akan datang.,

Salah satu alternatif yang digunakan dalam menilai nilai perusahaan adalah dengan menggunakan Tobin's Q. Rasio ini merupakan konsep yang sangat berharga karena menunjukan estimasi pasar keuangan saat ini tentang nilai hasil pengembalian dari setiap dolar investasi inkremental. Teori ini semula digunakan untuk mengukur resiko pada institusi keuangan seperti asuransi dan perbankan.
Rasio ini dapat memberikan informasi paling baik, karena rasio ini bisa menjelaskan berbagai fenomena dalam kegiatan perusahaan, seperti terjadinya perbedaan cross - sectional dalam pengambilan keputusan investasi, diversifikasi, hubungan antara kepemilikan saham manajemen dan nilai perusahaan, hubungan antara kinerja manajemen dengan keuntungan dalam akuisisi,kebijakan pendanaan dan investasi serta kompensasi ,Sukamulja ( 2004).

Tobin's Q dapat dirumuskan sebagai perbandingan nilai pasar asset dengan perkiraan jumlah uang yang harus dikeluarkan untuk mengganti seluruh asset tersebut pada saat ini. Konsep Tobin's Q dapat diformulasikan :

Tobin's Q = Debt MV of Stock + BV of Total Assets

MVEdiperolehdarihasilperkalianhargasaham penutupan(closing price)akhirtahun denganjumlah beredarpadaakhirtahun, sedangkan BVEd iperoleh darihasilselisihtotalassetsperusahaan dengan totalkewajibannya(Vinola, 2008:103).

Jika;Q >1 maka investasidalamaktiva menghasilkan laba daripadapengeluaran investasi. Namun jika $\mathrm{Q}<1$ maka investasi dalam aktiva tidaklah menarik

(Vinola,2008:100).

\subsection{Profitabilitas}

Profitabilitas merupakan kemampuan perusahaan memperoleh laba dalam hubungannya dengan penjualan, total aktiva maupun dengan modal sendiri (ekuitas) dalam periode tertentu ,Sartono (2001; 122). Pengembalian atas ekuitas merupakan indikator yang penting atas kekuatan perusahaan dalam jangka panjang. Pengembalian atas investasi, modal terutama jika dihitung selama periode satu tahun atau 
lebih, merupakan ukuran efektifitas menejerial perusahaan. Profitabilitas suatu perusahaan akan mempengaruhi kebijakan investor atas investasi yang dilakukan. Kemampuan perusahaan untuk menghasilkan laba akan dapat menarik investor untu menanamkan dananya guna memperluas usahanya, sebaliknya jika profitabilitas perusahaan rendah maka investor akan ragu dan bisa menarik dananya. Sedangkan bagi perusahaan sendiri profitabilitas dapat digunakan sebagai evaluasi atas efektifitas pengelolaan badan usaha tersebut

Return On Assets (ROA) merupakan salah saturasio profitabilitas. Rasio ini memberikan informasi besarnya laba yang diperoleh dari total asset yang dimiliki perusahaan. Return On Assets (ROA) menunjukan kemampuan perusahaan dalam menghasilkan laba dengan memanfaatkan total asset yang dimiliki perusahaan. Semakin tinggi ROA maka semakin baik produktifitas asset dalam memperoleh keuntungan bersih Dengan tingkat kemampuan laba yang tinggi merupakan informasi yang posistif maka tingkat kepercayaan investor akan meningkat karena tingkat pengembalian atas dividen akan semakin besar, hal ini akan berdampak pada harga saham dari perusahaan tersebut di pasar modal yang akan semakin meningkat sehingga ROA akan berpengaruh terhadap harga saham dan nilai perusahaan.

Formula untuk menghitung Return On Assets adalah:

$$
\text { ROA }=\frac{\begin{array}{c}
\text { Earning } \\
\text { After } \text { Tax }
\end{array}}{\text { Total }} \times 100 \%
$$

\subsection{Price Earning Ratio}

Menurut Tandelilin (2010; 375), PER adalah rasio yang menunjukan besarnya harga setiap satu rupiah yang harus dibayarkan investor untuk memperoleh satu rupiah earning perusahaan. PER melihat harga pasar saham relatif terhadap earning-nya. Perusahaan diharapkan tumbuh dengan tingkat pertumbuhan yang tinggi yang berarti mempunyai prospek yang baik biasanya mempunyai PER yang tinggi, sebaliknya perusahaan dengan nilai pertumbuhan yang rendah akan mempunyai PER yang rendah juga. Sedangkan menurut Ang (2007;324), Price Earning Ratio merupakan perbandingan antara harga pasar suatu saham dengan Earning Per Share dari saham yang bersangkutan.

Nilai PER yang rendah memberikan informasi kepada investor bahwa harga saham perusahaan pada kondisi murah dan layak untuk dibeli karena berpotensi untuk naik di masa mendatang. Nilai PER yang rendah berarti laba perusahaan semakin tinggi yan berarti nilai perusahaan dalam kondisi bagus.

Bagi pihak perusahaan dampak PER mencerminkan indikator yang baik untuk untuk menentukan stock return di masa akan datang, dimana semakin tinggi PER maka semakin tinggi juga harga saham perusahaan dan mengindikasikan nilai perusahaan bagus.

Nilai PER yang semakin tinggi menunjukan bahwa harga saham semakin meningkat dan dari peningkatan harga saham tersebut berpotensi mendatangkan keuntungan atas selisih harga saham yang terjadi. Hal ini berarti, bahwa dalam berinvestasi, investor memperhatikan price earning ratio sebagai salah satu pertimbangan dalam keputusan berinvestasi, dimana dengan 
meningkatnya nilai PER mengindikasikan nilai perusahaan juga meningkat. Dengan meningkatnya nilai PER, investor mengharapkan adanya pertumbuhan perusahaan yang lebih tinggi.

Untuk menghitung besarnya PriceEarning Ratio digunakan rumus:

PER

$$
=\frac{\text { Harga Saham }}{\text { Earning Per Share }}
$$

\subsection{Debt to Equity Ratio Keputusan Pendanaan}

Masalah penarikan dana (raising of fund) dianggap menarik karena setiap dana yang digunakan pasti mempunyai biaya yang sering disebut dengan biaya dana (cost of fund) (Mulyadi, 2006:236). Jika menggunakan dana yang berasal dari utang, jelas dana itu mempunyai biaya, minimal sebesar dari tingkat bunga, tetapi jika menggunakan modal sendiri (equity capital), maka masih harus mempertimbangkan oppurtunity cost bagi modal sendiri yang dimaksud.

Pengaturan antara perpaduan sumber modal mana yang akan diambil, maka diperlukan suatu pertimbanganpertimbangan tertentu dari perusahaan. Oleh sebab itu, kebijakan pendanaan merupakan suatu kebijakan yang membahas mengenai sumber dana yang akan digunakan untuk membiayai suatu investasi yang menyangkut kombinasi yang optimal dari penggunaan

$$
\text { DER }=\frac{\text { Total Hutang }}{\text { Total Ekuitas }}
$$

berbagai sumber dana.

Mulyadi (2006:236), berpendapat bahwa keputusan pendanaan akan menyangkut penentuan kombinasi berbagai sumber dana yang pada dasarnya akan dibagi menjadi dua:

a. Pendanaan ekstern yang akan mengarah pada pengambilan keputusan mengenai struktur modal, yakni menentukan proporsi antara hutang jangka panjang dan modal sendiri. Hal ini akan nampak pada debt to equity ratio perusahaan tersebut.

b. Pendanaan intern yang diaplikasikan menurut penentuan kebijakan deviden yang digambarkan melalui dividend payout ratio.

Struktur modal yang baik minimal memiliki proposional antara sumber dana internal dan eksternal sehingga segala kewajiban dapat dilunasi. Kim (1982) dalam Imam dan Indra (2000) menyatakan bahwa tolak ukur struktur modal yang optimal ditunjukkan dengan leverage keuangan yang kecil, dengan leverage yang kecil perusahaan cenderung mengurangi risiko perusahaan (atau risiko tidak sistimatis).

Dalam penelitian ini struktur modal diproksikan dengan Debt to Equity Ratio (DER). Debtto Equity Ratio merupakan rasio hutang yang digambarkan dengan perbandingan antara seluruh hutang, baik hutang jangka panjang maupun jangka pendek dengan modal sendiri ,Ang ( 2007; 89). Semakin tinggi beban hutang (DER) maka resiko yang ditanggung juga semakin besar. Hal ini akan mempengaruhi tingkat kepercayaan investor terhadap perusahaan, selanjutnya akan mempengaruhi nilai perusahaan.

Secara matematis DER dapat diformulasikan dengan, Brigham dan Houston ( 2006).

\subsection{Earning Per Share}

Earning Per Share (EPS) menurut Baridwan (2004; 448), laba per lembar saham adalah jumlah pendapatan yang diperoleh dalam satu periode untuk tiap lembar saham yang beredar dan akan dipakai oleh pimpinan perusahaan untuk menentukan besarnya dividen yang akan dibagikan. Sedangkan menurut Fabozzi (2000; 361), EPS merupakan salah satu angka yang dihitung dengan membagi laba yang tersedia bagi para pemegang saham biasa (EAT dikurangi 
saham preferen) dengan rata tertimbang jumlah lembar saham yang beredar selama periode perhitungan dilakukan

Investor membeli saham suatu perusahaan adalah untuk mendapatkan dividen, jika nilai laba per saham kecil maka kecil pula kemungkinan perusahaan untuk membagikan dividen. Maka dapat diartikan bahwa investor akan lebih meminati saham yang memiliki earning per share tinggi dibandingkan saham yang memiliki earning per share yang rendah. Earning per Share yang rendah cenderung membuat harga saham turun yang juga mengakibatkan akan menurunnya nilai perusahaan.

Secara matematis Earning Per Share (EPS) dapat diformulasikan:

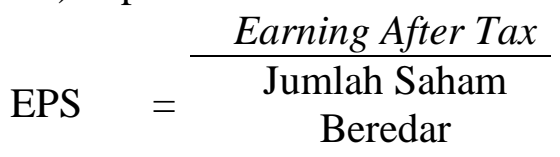

\section{METODE PENELITIAN}

\subsection{Desain Penelitian}

Jenis penelitian ini merupakan penelitian kausal asosiatif, karena penelitian ingin mengetahui pengaruh profitabilitas, return on asset,price earningratio, debt to equity ratio dan earning per share terhadap nilai perusahaan. Desain kausalitas berguna untuk mengukur hubungan dan pengaruh antar variabel independen yang digunakan terhadap variabel dependen

\subsection{Populasi dan Sampel}

Populasi dalam penelitian ini adalah seluruh perusahaan sektor pertanian yang terdaftar di Bursa Efek Indonesia periode 2008-2014.

Sampel penelitian ditentukan dengan menggunakan teknik purposive sampling, yaitu teknik penentuan sampel berdasarkan kriteria tertentu.

\subsection{Definisi varriabel operasional}

\begin{tabular}{|c|c|c|c|c|}
\hline Variabel & Konsep & & Rumus & Skala \\
\hline $\begin{array}{l}\text { Nilai Penusahaan } \\
\text { (Tobins'q) }\end{array}$ & $\begin{array}{l}\text { Perbandingan Harga } \\
\text { Pasar SahamdanNilai } \\
\text { Buku dengan Total } \\
\text { Aset }\end{array}$ & Tobins'q & $=\frac{(\text { MV of Stock }+B \text { of Stock })}{\text { Total Assets }}$ & Rasio \\
\hline $\begin{array}{l}\text { Retum OnAssets } \\
\text { (ROA) }\end{array}$ & $\begin{array}{l}\text { Perbandingan Laba } \\
\text { Bersih setelahPajak } \\
\text { dengan Total Aktiva }\end{array}$ & $\mathrm{ROA}$ & $\frac{\text { EAT }}{\text { Total Aktiva }}$ & Rasio \\
\hline $\begin{array}{l}\text { Price Earning } \\
\text { Ratio(PER) }\end{array}$ & $\begin{array}{l}\text { Perbandingan Harga } \\
\text { SahamdenganLaba per } \\
\text { Lembar Saham }\end{array}$ & PER & $\frac{\text { Harga Saham }}{\text { EPS }}$ & Rasio \\
\hline $\begin{array}{l}\text { Debt to Equity } \\
\text { Ratio(DER) }\end{array}$ & $\begin{array}{l}\text { Perbandingan Total } \\
\text { Hutang dengan Total } \\
\text { Ekuitas }\end{array}$ & DER & $\frac{\text { Total Hutang }}{\text { Total Ekuitas }}$ & Rasio \\
\hline $\begin{array}{l}\text { Earning } P \text { er } \\
\text { Share } \\
\text { (EPS) }\end{array}$ & $\begin{array}{l}\text { Perbanding Laba Bersih } \\
\text { setelah Pajak dengan } \\
\text { Jumlah Saham Beredar }\end{array}$ & EPS & $=\frac{\text { EAT }}{\text { Jumlah Saham Beredar }}$ & Rasio \\
\hline
\end{tabular}

\subsection{Kerangka Pemikiran dan Hipotesisi}

Berdasarkan teori dan fenomena hasil penelitian yang pernah dilakukan, kerangka pemikiran penelitian dan hipotesisi penelitian adalah sebagai berikut:

\subsubsection{Kerangka Pemikiran}

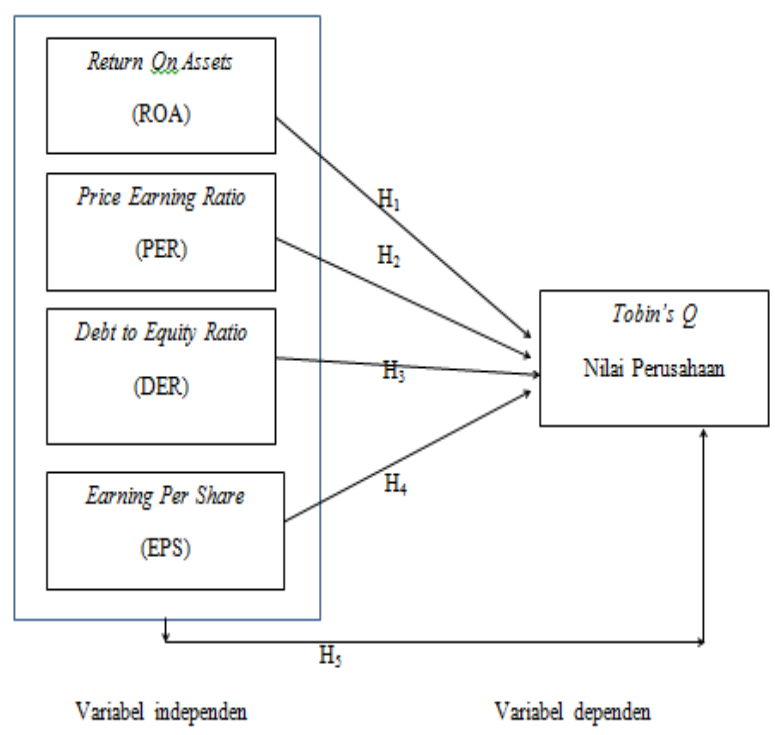

\subsubsection{Hipotesis Penelitian}

$\mathrm{H1}$ : there is influence between return on assets with a value of companies 
in the agricultural sector companies listed on the indonesia stock exchange

$\mathrm{H}_{2}$ : Terdapat pengaruh antara Price Earning Ratio dengan Nilai Perusahaan pada perusahaan sektor pertanian yang terdaftar di Bursa Efek Indonesia.

$\mathrm{H}_{3}$ : Terdapat pengaruh antara Debt to Equity Ratio dengan Nilai Perusahaan pada perusahaan sektor pertanian yang terdaftar di Bursa Efek Indonesia.

$\mathrm{H}_{4} \quad$ : Terdapat pengaruh antara Earning Per Share dengan Nilai Perusahaan pada perusahaan sektor pertanian yang terdaftar di Bursa Efek Indonesia.

$\mathrm{H}_{5}$ : Terdapat pengaruh secara bersama-sama antara Return On Assets, Price Earning Ratio, Debt to Equity Ratio dan Price Earning Ratio dengan Nilai Perusahaan pada perusahaan sektor pertanian yang terdaftar di Bursa Efek Indonesia.

\subsection{Teknik dan Analisis Data}

Metode analisis data digunakan juga untuk menguji hipotesa yang telah dirumuskan, maka model yang dipergunakan dalam penelitian ini adalah model regresi data panel ( kombinasi time series dan cross section) dengan menggunakan program aplikasi statistic computer Eviews 8.0.

\section{HASIL PENELITIAN DAN PEMBAHASAN \\ 4.1.Hasil Penelitian \\ 4.1.1.Uji Model Barpasangan}

\section{- Uji Chow}

RedundantFixed Effects Tests

Equation:Unittled

Test cross-section fixed effects

\begin{tabular}{lrrr}
\hline \hline Effects Test & Statistic & d.f. & Prob. \\
\hline \hline Cross-sectionF & 1.574828 & $(7,44)$ & 0.1602 \\
Cross-sectionChi-square & 12.520265 & 7 & 0.0847 \\
\hline \hline
\end{tabular}

Dari hasil analisa data diatas diperoleh nilai Probabilita Cross Section sebesar 0.0847 atau $8,47 \%$ yang berarti nilai probabilita tersebut lebih besar dari 5\%, sehingga $\mathrm{H}_{0}$ diterima berarti model yang dipilih adalah Coomon Effect Model

\section{Uji Hausman}

\begin{tabular}{|c|c|c|c|}
\hline Test Summary & $\begin{array}{l}\text { Chi-Sq. } \\
\text { Statistic }\end{array}$ & Chi-Sq. d.f. & Prob. \\
\hline Cross-section random & 6.307001 & 4 & 0.1774 \\
\hline
\end{tabular}

Berdasarkan tabel uji Hausman diatas diperoleh nilai probabilita crosssection random effect sebesar 0,1774 atau $17,74 \%$, berarti nilai probalita tersebut lebih besar dari 5\%, sehingga model yang diterima adalah Random Effect Model (REM) 


\section{Uji hipotesis Lagrange Multiplier}

Lagrange multiplier (LM) test for panel data

Date: 01/27/16 Time: 17:01

Sample: 20082014

Total panel observations: 56

Probability in ()

\begin{tabular}{lccc}
\hline \hline $\begin{array}{l}\text { Null (no rand. effect) } \\
\text { Alternative }\end{array}$ & $\begin{array}{c}\text { Cross-section } \\
\text { One-sided }\end{array}$ & $\begin{array}{c}\text { Period } \\
\text { One-sided }\end{array}$ & Both \\
\hline \hline Breusch-Pagan & 0.483757 & 0.505833 & 0.989590 \\
& $(0.4867)$ & $(0.4769)$ & $(0.3198)$ \\
Honda & -0.695527 & -0.711219 & -0.994719 \\
& $(0.7566)$ & $(0.7615)$ & $(0.8401)$ \\
King-Wu & -0.695527 & -0.711219 & -0.994409 \\
& $(0.7566)$ & $(0.7615)$ & $(0.8400)$ \\
GHM & - & - & 0.000000 \\
& - & - & $(0.7500)$ \\
\hline \hline
\end{tabular}

Dari hasil out putsoft ware eviews 8 dapat dilihat bahwa Probability BreuschPagan diperoleh nilai sebesar 0,4867 $(48,67 \%)$ berarti nilai probabilita tersebut lebih besar dari 5\%, maka $\mathrm{H}_{0}$ diterima, berarti model yang digunakan adalah Fixed Effect Model

\section{Pengujian Model Regresi Data Panel}

\begin{tabular}{|c|c|c|c|}
\hline $\mathrm{N}_{0}$ & Metode & Pengujalan & Hasil \\
\hline 1 & Chow-Test & Common Effect vs Fixed Effect & Common Effect \\
\hline 2 & Houlsman Test & RandomEffect vs Fired Effect & RandomEffect \\
\hline 3 & $\begin{array}{l}\text { Lagrange Multiplier } \\
\text { (LM-Test) }\end{array}$ & Fixed Effect vs Random Effect & Fired Effect \\
\hline
\end{tabular}

\subsubsection{Hasil estimasi dengan metode} Date: 01/25/16 Time: $14: 18$

Sample: 20082014

Periods included: 7

Cross-sections included: 8

Total panel (balanced) observations: 56

\begin{tabular}{|c|c|c|c|c|}
\hline Variable & Coefficient & Std. Error & t-Statistic & Prob. \\
\hline $\mathrm{c}$ & 0.881051 & 0.696049 & 2.127797 & 0.0390 \\
\hline ROA & 0.038355 & 0.028964 & 1.324196 & 0.1923 \\
\hline PER & 0.030440 & 0.022797 & 1.335242 & 0.1887 \\
\hline DER & -0.123032 & 0.176338 & -0.697707 & 0.4890 \\
\hline EPS & 0.001925 & 0.001151 & 1.672252 & 0.0021 \\
\hline \multicolumn{5}{|c|}{ Effects Specification } \\
\hline \multicolumn{5}{|c|}{ Cross-section fixed (dummyvariables) } \\
\hline R-squared & 0.606113 & \multicolumn{2}{|c|}{ Mean dependent var } & 1.830191 \\
\hline Adjusted R-squared & 0.557641 & \multicolumn{2}{|c|}{ S.D. dependent var } & 1.281258 \\
\hline S.E. of regression & 1.103935 & \multicolumn{2}{|c|}{ Aksike info criterion } & 3.223048 \\
\hline Sum squared resid & 53.62157 & \multicolumn{2}{|c|}{ Schwarz criterion } & 3.657052 \\
\hline Log likelihood & -78.24535 & \multicolumn{2}{|c|}{ Hannan-Quinn criter. } & 3.391311 \\
\hline F-statistic & 2.735286 & \multicolumn{2}{|c|}{ Durbin-Watson stat } & 1.657062 \\
\hline Prob(F-statistic) & 0.008762 & & & \\
\hline
\end{tabular}

\section{Fixed Effect}

\subsection{Pengujian Hipotesis}

Hasil estimasi faktor-faktor yang mempengaruhi Nilai Perusahaan (Tobins'q) yaitu return on asset (ROA), price earning ratio (PER), debt to equity ratio (DER) dan earning per share (EPS) dengan menggunakan Fixed Effect Model, maka persamaannya dapat ditulis:

\section{Nilai Perusahaan $($ Tobins' $q)=$} 0,8811 + 0,0384 ROA + 0,0304 PER 0,1230 DER + 0,0019 EPS

Dari persamaan diatas, selanjutnya dilakukan pengujian terhadap masingmasing koefisien regresi data panel yang mempengaruhi Nilai Perusahaan dengan menggunakan uji- t.

$\mathrm{H}_{1} \mathrm{ROA}$ berpengaruh signifikan terhadap Nilai Perusahaan.

Dari hasil uji statistik diperoleh nilai probabilitas $\mathrm{ROA}=0,1923$, dengan tingkat keyakinan $95 \%$, maka $0,1923>0,05$ berarti hipotesis ditolak, sehingga dapat disimpulkan bahwa variabel ROA berpengaruh positif tidak signifikan terhadap Nilai Perusahaan.. Interprestasi $\beta_{1}=0,0384$ adalah jika terjadi kenaikan ROA sebesar 
1\% maka akan mengakibatkan kenaikan Nilai Perusahaan sebesar 0,0384

$\mathrm{H}_{2}$ :PER berpengaruh signifikan terhadap Nilai Perusahaan.

Dari hasil uji statitik diperoleh nilai probabilitas PER $=0,1887$, dengan tingkat keyakinan $95 \%$, maka $0,1887>0,05$, berarti hipotesis ditolak, sehingga dapat disimpulkan bahwa variabel PER berpengaruh positif tidak signifikan terhadap Nilai Perusahaan. Interprestasi nilai $\beta_{2}=0,0304$ adalah jika terjadi kenaikan PER sebesar 1 maka akan mengakibatkan kenaikan Nilai Perusahaan sebesar 0,0304

$\mathrm{H}_{3}$ :DER berpengaruh signifikan terhadap Nilai Perusahaan.

Dari hasil uji statistik Fixed Effect Model yang digunakan diperoleh nilai probabilitas $\mathrm{DER}=0,4890$, dengan tingkat keyakinan $95 \%$, maka $0,4890>0,05$, berarti hipotesisditolak. Hal ini dapat disimpulkan bahwa variabel DER berpengaruh negatif tidak signifikan terhadap Nilai Perusahaan. Interprestasi $\beta_{3}=-0,1203$ adalah jika terjadi kenaikan DER sebesar 1 maka akan mengakibatkan Nilai Perusahaan turun sebesar 0,1203.

$\mathrm{H}_{4}$ :EPS berpengaruh signifikan terhadap Nilai Perusahaan.

Dari model yang digunakan diperoleh koefisien regresi variabel Earning Per Share (EPS) $\beta_{4}=0,0019$. Dari hasil uji statistik yang digunakan diperoleh nilai probabilitas $=0,0021$, dengan tingkat keyakinan 95\%, maka $0,0021<0,05$, berarti hipotesis diterima. Dapat disimpulkan bahwa variabel EPS berpengaruh positif signifikan terhadap Nilai Perusahaan.Interprestasi $\beta_{3}=0,0019$, adalah jika EPS naik 1 maka akan mengakibatkan Nilai Perusahaan naik sebesar 0,0019 .

Uji Simultan (Uji-F)

Hasil uji-F dari model yang digunakan menunjukan F-statistik sebesar 27,3529 ,dengan tingkat keyakinan 95\%, nilai probabilitas 0,0018 lebih kecil dari $\alpha=0,05$, berarti $\mathrm{H}_{0}$ ditolak. Hal ini dapat disimpulkan bahwa variabel ROA, PER, DER dan EPS secara bersama-sama (simultan) mempengaruhi Nilai Perusahaan dengan tingkat keyakinan $95 \%$.

\section{Uji Koefisien Determinasi}

Dalam penelitian ini variabel bebas yang digunakan lebih dari 2, maka uji yang digunakan adalah uji koefisien determinasi yang disesuaikan ( $\mathrm{R}^{2}$ adjusted). Nilai $\mathrm{R}^{2}$ adjusted penelitian dengan Fixed Effect Model sebesar 55,76\%, yang berarti seluruh variabel bebas dalam penelitian ini dapat menjelaskan Nilai Perusahaan sebesar $55,76 \%$, sedangkan sisanya 44,24\% dijelaskan oleh faktor-faktor lain yang tidak diikut sertakan dalam penelitian.

\subsection{Pembahasan}

Penelitian yang dilakukan Wobowo dan Aisjah (2013) yang berkesimpulan bahwa terdapat pengaruh positif tidak signifikan antara return on asset terhadap nilai perusahaan. Sedangkan hasil penelitian ini berbeda dengan hasil penelitian yang dilakukan oleh Wulandari (2013) yang berkesimpulan bahwa Return On Asset berpengaruh positif signifikan terhadap nilai perusahaan.

Dari data penelitian terlihat perusahaan dengan kenaikan total asset yang tinggi tidak diikuti oleh kenaikan laba bersih (net income). Hal ini dapat disebabkan oleh kinerja manajemen dalam menggunakan asset perussahaan yang dimiliki belum bisa dikelola secara efisien dan efektif yang mengakibatkan laba bersih yang dihasilkan 
perusahaan tidak sebanding dengan asset yang dimiliki perusahaan sedemikian besar. Sedangkan net income merupakan hal yang menjadi perhatian utama investor.

Hasil penelitian yang dilakukan oleh Sartini dan Purbawangsa (2012), Gayatri dan Mustanda (2013), yang menyimpulkan bahwa priceearning ratio(PER) berpengaruh positif signifikan terhadap nilai perusahaan.

Dari hasil penelitian ini nilai PER berpengaruh tidak signifikan terhadap nilai perusahaan hal ini mengindikasikan investasi yang dilakukan perusahaan memberikan hasil tidak memuaskan mengakibatkan kinerja perusahaan akan menurun sehingga direspon negatif oleh investor dan akhirnya harga saham menjadi turun dan nilai perusahaan juga turun.

Hasil penelitian variabel DER, sejalan dengan hasil penelitian yang dilakukan Hidayati (2010), yang berkesimpulan bahwa, debt to equity ratio berpengaruh negatif tidak signifikan terhadap nilai perusahaan.

Hasil penelitian Nasehah dan Widyarti ( 2012), berkesimpulan debt to equity ratio berpengaruh negatif signifikan terhadap nilai perusahaan. Hasil penelitian yang dilakukan Fenandar dan Rahardja (2012), Indrawati dan Yuliathini (2013), berkesimpulan bahwa debt to equity ratio berpengaruh positif tidak signifikan terhadap nilai perusahaan. Sedangkan penelitian yang dilakukan oleh Irayanti dan Tumbel (2014), Gayatri dan Mustanda (2013) berkesimpulan bahwa debt to equity ratio berpengaruh positif signifikan terhadap nilai perusahaan.

Nilai struktur modal secara parsial dalam hasil penelitian ini memiliki pengaruh negatif tidak signifikan terhadap nilai perusahaan. Ini mengindikasikan bahwa semakin tinggi atau rendah hutang yang dimiliki sebuah perusahaan tidak akan mempengaruhi nilai perusahaan, hal ini dapat disebabkan karena di pasar modal pergerakan harga saham dan penciptaan nilai tambah perusahaan dapat disebabkan oleh faktor psikologis pasar.

Hasil penelitian variabel EPS ini tidak berbeda dengan hasil penelitian yang dilakukan oleh Sartini dan Purbawangsa (2012), Irayanti dan Tumbel (2014) yang berkesimpulan bahwa earning pershare berpengaruh positif terhadap nilai perusahaan.

Earning Per Share merupakan komponen pertama yang harus dinilai untuk melihat kinerja suatu saham, sehingga earning per share menjadi variabel berpengaruh signifikan terhadap harga saham, harga saham semakin tinggi mengakibatkan nilai perusahaan semakin tinggi.

Earning Per Share menunjukan profitabilitas perusahaan pada setiap lembar saham. Besarnya nilai EPS mempengaruhi tingkat kepercayaan investor untuk berinvestasi pada perusahaan tersebut. Sedangkan nilai perusahaan berkaitan dengan harga saham perusahaan di pasar modal.

\section{Kesimpulan}

1. Dari empat variabel yang diteliti, ternyata hanya satu variabel yang berpengaruh positif signifikan terhadap Nilai Perusahaan yaitu variabel Earning Per Share.

2. Sedangkan variabel yang lain yaitu Return On Asset dan Price EarningRatio berpengaruh positif tidak signifikan terhadap Nilai Perusahaan.

3. Variabel Debt to Equity Ratio berpengaruh negatif tidak signifikan terhadap Nilai Perusahaan

4. Dari hasil uji statistik variabel independen yang paling besar pengaruhnya terhadap Nilai Perusahaan adalah Return On Asset.

5. Hasil dari uji-F, terbukti bahwa nilai $F$ hitung lebih besar dari F tabel. Artinya seluruh variabel independen secara bersama-sama (simultan) berpengaruh 
signifikan terhadap Nilai Perusahaan sebagai variabel dependen.

\section{Saran}

1. Untuk penelitian selanjutnya indikator penelitian dapat diganti dengan proxy yang lain atau ditambah dengan variabel yang lain.

2. Untuk penelitian selanjutnya dapat ditambah menjadi seluruh perusahaan yang listing di BEI sehingga penelitian dapat digeneralisasi dan lebih menjelaskan variabilitas data yang sesungguhnya. 


\section{Daftar Pustaka}

Ang, Robert, 2007, Buku Pintar Pasar Modal Indonesia. Jakarta: Mediasoft.

Ansori,Mokhamat dan Denica H.N, 2010, "Pengaruh Keputusan Investasi Keputusan Pendanaan dan Kebijakan Dividen terhadap Nilai Perusahaan pada Perusahaan yang tergabung dalam Jakarta Islamic Index Studi pada BEI." Analisis Manajemen. Vol. 4. No. 2, 2010: $153-175$.

Baridwan, Zaki, 2004, Intermediate Accounting. 8 th Ed. Yogyakarta: BPFE

Brigham,E.E dan J.F. Houston , 2006 , Manajemen Keuangan. Edisi Kedelapan. Buku 1. Terjemahan: Ali Akbar Yulianto. Jakarta: Erlangga

Brigham,E.E dan Michael C. Ehrhardt, 2005, Financial Management, Theory and Practice, International Student Edition, South Western Cengage Learning

Donalson, Gordon , 1961, Corporate Debt Capacity, Boston, Harvard Business School Press, 22-31.

Dwi Asri, Jatnika, 2011," Pengaruh EPS, DER dan Pertumbuhan Aset terhadap Harga Saham (Studi Kasus pada Perusahaan Sektor Pertanian yang LIsting di Bursa Efek Indonesia tahun 2003-2008)" Jurnal Ekono INsentif Kopwil 4. Vol 5 No.1. Juli 2011,ISSN-0640, hal.1-7.

Fabozzi.J.Frank, 2000, Manajemen Investasi II. Alih Bahasa: Tim Penerjemah Salemba Empat. Jakarta: Salemba Empat.

Fenandar Gany Ibrahim dan Surya Raharja, 2012, "Pengaruh Keputusan Investasi, Keputusan Pendanaan, dan Kebijakan Dividen terhadap Nilai Perusahaan." Diponegoro Journal of Accounting. Vol. 1. No. 2, 2012: 1 -10.

Gayatri,Luh.P.R dan I Ketut Mustanda, 2013, "Pengaruh Struktur Modal, Kebijakan Dividen dan Keputusan Investasi terhadap Nilai Perusahaan." E - Jurnal Manajemen Universitas Udayana. Vol. 3. No. 6

Ghozali, Imam, 2005, Aplikasi Analisis Multivariate dengan Program SPSS. Semarang: Badan Penerbit Universitas Diponegoro.

Gujarati, Damodar, 2003, Ekonometrika Dasar. Alih Bahasa: Sumarno Zain. Jakarta: Erlangga

Hartono,Jogianto, 2010, Teori Portofolio dan Analisis Investasi. Yogyakarta: BPFE.

Hidayati, Eva Eko. 2010. Analisis Pengaruh DER, DPR, ROE dan Size terhadap PBV Perusahaan Manufaktur yang Listing di BEI Periode 2005 - 2007. Tesis Program Pasca Sarjana Magister Manajemen Universitas Diponegoro, (tidak dipublikasikan)

Husnan, Suad, 2005, Dasar-dasar Teori Portofolio dan Analisis Sekuritas. Yogyakarta: UPP AMP.YKPN 
Irayanti,Desi dan Altje L. Tumbel, 2014, "Analisis Kinerja Keuangan Pengaruhnya terhadap Nilai Perusahaan pada Industri Makanan dan Minuman di BEI." Jurnal EMBA. Vol. 2. No. 2, 2014: 1473 - 1482.

Imam,Subekti dan Indra Wijaya Kesuma. 2000.”Asosiasi antara Set Kesempatan Investasi dengan Kebijakan Pendanaan dan Deviden Perusahaan serta Implikasinya terhadap Perubahan Harga Saham". SNA III, IAI, Surabaya, hal 820-850.

Jensen, MIchael C, 1986. Agency Cost of free Cash Flow, Coorporate finace, and Take over. American Economics Review, Vol. 76.

Keown,Arthur.J, John D, Martin, J William Petty, David F. Scott, Jr, 2005. Financial Management :Principle and Applicatian, International Edition, Pearson - Prentice Hall

Mulyadi, 2006, Akuntansi Biaya, Yogyakarta: STIE YKPN.

Myers, S. C, 2001, "Capital Structure." The Journal of Ecomomic Perspective Vol 15. 2, 2001: $81-102$.

Nasehah Durrotun dan Endang Tri Widyarti, 2012, "Analisis Pengaruh ROE, DER, DPR, Growth dan Firm Size terhadap Price to Book Value (PBV) (Studi Kasus pada Perusahaan Manufaktur yang Listed di BEI 2007-2010)." Diponegoro Journal of Management. Vol 1. No. 1, 2012: 1 - 9.

Poernamawatie, Fahmi, 2008, "Pengaruh Price to Book Value dan Price Earning Ratio terhadap Return saham pada Perusahaan Manufaktur yang terdaftar di Bursa Efek Indonesia." Jurnal Manajemen Gajayana Vol. 5 No.2, 2008: 105 - 118.

Riyanto, Bambang, 2008, Dasar-Dasar Pembelanjaan Perusahaan. Yogyakarta:

Sartini, Luh P.N dan Ida Bagus Anom Purbawangsa, 2012, "Pengaruh Keputusan Investasi, Kebijakan Dividen serta Keputusan Pendanaan terhadap Nilai Perusahaan Manufaktur di Bursa Efek Indonesia". E - Jurnal Manajemen Universitas Udayana. Vol. 3. No. 6

Sartono, Agus, 2001, Manajemen Keuangan Teori dan Aplikasi, Edisi 4. Yogyakarta: BPFE Yogyakarta.

Sjahrial, Dermawan, 2014, Manajemen Keuangan Lanjutan, Edisi Revisi. Jakarta: Mitra Wacana Media.

Stiglitz, Joseph, E, 1969, "Re- Examinatioan of Modigliani-Miller Theorem" American Economic Review, 784 - 793

Sudiyatno, Bambang dan Ellen Puspitasari. 2010, "TOBINS'Q dan ALTMAN'Z SCORE,sebagai indikator pengukuran kinerja, Kajian Akuntansi Vol. 2. No.1: 19 - 21

Sugiyono, 2006, Metode Penelitian Bisnis. Bandung: CV. Alfabeta.

Suharli, Michell, 2006, "Faktor-faktor yang Mempengaruhi Nilai Perusahaan pada perusahaan Go Public di Indonesia." Kumpulan Makalah Simposium Nasional Akuntansi 8. Solo. 
Sukamulja, Sukmawati, 2004, "Good Corporate Governance di Sektor Keuangan: Dampak GCG terhadap Kinerja Perusahaan( Kasus di BEI)." Benefit vol.8 No 1.

Tandelilin, Eduardus, 2010, Analisis Investasi dan Manajemen Portofolio, Edisi Pertama. Yogyakarta: Badan Penerbit Universitas Gajah Mada.

Wardjono, 2010, "Analisis Faktor-Fakttor yang Mempengaruhi Price to Book Value dan Implikasinya pada Return Saham (Studi Kasus pada Perusahaan Manufaktur yang Terdaftar di BEI)." Dinamika Keuangan dan Perbankan.Vol.2.No.1, 2010: 83-96.

Wibowo,Ramadani dan Siti Aisjah, 2012 "Pengaruh Profitabilitas, Kepemilikan Manajerial, Kebijakan Dividen dan Leverage terhadap Nilai Perusahaan (Studi pada Perusahaan Manufaktur yang Terdaftar di BEI Periode 2009 - 2011)." Malang. 